\title{
Quantitative method for determining serum alkaline phosphatase isoenzyme activity II. Development and clinical application of method for measuring four serum alkaline phosphatase isoenzymes
}

\author{
M D S SHEPHARD, M J PEAKE, R N WALMSLEY \\ From the Department of Biochemistry and Chemical Pathology, Flinders Medical Centre, Bedford Park, \\ South Australia
}

SUMMARY A method for quantitating the liver, bone, intestinal and placental alkaline phosphatase activity of serum, using an algorithm for converting selective inactivation by guanidine hydrochloride, L-phenylalanine, and heat into equivalent isoenzyme activity is described. The method can individually quantify mixtures of isoenzymes to within a margin of $3 \%$; it has acceptable reproducibility and has been used to develop both age and sex related reference ranges. Analysis time is about 30 minutes. The clinical reliability of this method has been shown in a study of 101 patients, in $79 \%$ of whom isoenzyme results were compatible with the final clinical diagnosis; in $10 \%$ a clinical diagnosis resulted from isoenzyme analysis, and in a further $11 \%$ the source of the increased alkaline phosphatase activity was identified and supported by electrophoresis, with a definite clinical diagnosis yet to be made.

In the clinical biochemistry laboratory an increased serum alkaline phosphatase activity [EC 3.1.3.1] is often an unexpected finding. The source of the increased alkaline phosphatase activity can be investigated by performing other liver function testsfor example, alanine aminotransferase [ALT, EC 2.6.1.2], gamma-glutamyltransferase $[\gamma \mathrm{GT}, \quad \mathrm{EC}$ 2.3.2.2], $5^{\prime}$-nucleotidase [ $5^{\prime} \mathrm{NT}$, EC 3.1.3.5], or by isoenzyme analysis. The latter studies generally entail electrophoretic or selective inactivation techniques. Considerable skill, however, is required to resolve and interpret isoenzyme components using electrophoresis, and results are usually qualitative rather than quantitative. Further difficulties can be experienced in separating bone and liver fractions, the main diagnostic problem. ${ }^{1}$ Although recent work using wheat germ lectins has increased the discrimination of electrophoresis ${ }^{2}$ and provided a means of isolating about $80 \%$ of the bone isoenzyme by precipitation, ${ }^{3}$ it is our belief and that of other workers ${ }^{1}$ that the analytical potential of selective inhibition techniques has been unnecessarily overlooked.

In a previous paper ${ }^{4}$ the usefulness of a new reagent

Accepted for publication 26 March 1986 for inhibition studies, guanidine hydrochloride, was described. In this paper further selective inhibition techniques entailing the use of heat ${ }^{5}$ and Lphenylalanine $^{6}$ were combined with the use of guanidine hydrochloride to develop an algorithm for the direct quantitation of alkaline phosphatase isoenzymes, including any placental or carcinoplacental alkaline phosphatase. The possible contribution of these fractions in chemical inhibition studies has been noted but not resolved by earlier investigators. ${ }^{\text {? }}$

\section{Material and methods}

ALKALINE PHOSPHATASE ISOENZYMES The sources of the four major isoenzymes of alkaline phosphatase were as described previously. ${ }^{4}$

MEASUREMENT OF TOTAL AND GUANIDINE HYDROCHLORIDE STABLE ALKALINE PHOSPHATASE ACTIVITY

Both methods were carried out, as described previously. ${ }^{4}$ Table 1 shows the instrument settings.

INHIBITION STUDIES WITH L-PHENYLALANINE L-phenylalanine (Sigma Chemicals, United States) was accurately weighed out and dissolved in AMP buffer (Monotest Alkaline Phosphatase kit, Boeh- 
Table 1 Reaction conditions on Cobas Bio for measuring alkaline phosphatase isoenzyme activity

\begin{tabular}{|c|c|c|c|}
\hline Instrument settings & $\begin{array}{l}\text { A Total activity, L-phenylalanine } \\
\text { inhibition, and heat stability }\end{array}$ & $\begin{array}{l}\text { B Guanidine hydrochloride } \\
\text { inhibition }\end{array}$ & $\begin{array}{l}\text { C Kinetic studies with } \\
\text { L-phenylalanine }\end{array}$ \\
\hline $\begin{array}{l}1 \text { Units } \\
2 \text { Calculation factor } \\
3 \text { Standard } 1 \text { concentration } \\
4 \text { Standard } 2 \text { concentration } \\
5 \text { Standard } 3 \text { concentration } \\
6 \text { Limit } \\
7 \text { Temperature }\left({ }^{\circ} \mathrm{C}\right) \\
8 \text { Type of analysis } \\
9 \text { Wavelength }(\mathrm{nm}) \\
10 \text { Sample volume }(\mu \mathrm{l}) \\
11 \text { Diluent volume }(\mu \mathrm{l}) \\
12 \text { Reagent volume }(\mu \mathrm{l}) \\
13 \text { Incubation time }(\text { seconds) } \\
14 \text { Start reagent volume }(\mu \mathrm{l}) \\
15 \text { Time of first reading }(\mathrm{seconds}) \\
16 \text { Time interval (seconds) } \\
17 \text { No of readings } \\
18 \text { Blanking mode } \\
19 \text { Printout mode }\end{array}$ & $\begin{array}{l}\mathrm{U} / 1 \\
2688 \\
0 \\
0 \\
0 \\
1 \cdot 5 \\
37 \cdot 0 \\
2 \\
405 \\
05 \\
30 \\
150 \\
120 \\
0 \\
30 \cdot 0 \\
10 \\
20 \\
1 \\
1\end{array}$ & $\begin{array}{l}U / 1 \\
2688 \\
0 \\
0 \\
0 \\
1 \cdot 5 \\
37 \cdot 0 \\
2 \\
405 \\
05 \\
30 \\
150 \\
300 \\
0 \\
170 \cdot 0 \\
10 \\
07 \\
1 \\
2\end{array}$ & $\begin{array}{l}\mathrm{U} / 1 \\
2688 \\
0 \\
0 \\
0 \\
1 \cdot 5 \\
37 \cdot 0 \\
2 \\
405 \\
05 \\
30 \\
150 \\
120 \\
0 \\
0 \cdot 5 \\
20 \\
30 \\
1 \\
3\end{array}$ \\
\hline
\end{tabular}

ringer Mannheim, West Germany; catalogue number 396494) to give the desired concentration of inhibitor. Substrate and magnesium cofactor tablets were then added to $11.5 \mathrm{ml}$ of this reagent. The combined reagent was mixed until dissolved and prewarmed for 10 minutes at $37^{\circ} \mathrm{C}$ before use. The addition of inhibitor did not affect the $\mathrm{pH}$ of reagent.

Final concentrations of L-phenylalanine investigated were $2.5 \mathrm{mmol} / 1(0.41 \mathrm{~g} / \mathrm{l}), 5 \mathrm{mmol} / 1(0.83 \mathrm{~g} / \mathrm{l})$, $10 \mathrm{mmol} / 1 \quad(1.65 \mathrm{~g} / \mathrm{l}), \quad 20 \mathrm{mmol} / \mathrm{l} \quad(3.30 \mathrm{~g} / \mathrm{l}), \quad$ and $50 \mathrm{mmol} / 1 \mathrm{(}(8.26 \mathrm{~g} / \mathrm{l})$. Alkaline phosphatase activity remaining in the presence of $\mathrm{L}$-phenylalanine was determined in duplicate for each isoenzyme on the Cobas Bio, using the instrument settings shown in table 1 (column A) - that is, the same settings as those used for the determination of total alkaline phosphatase.

\section{HEAT STABILITY STUDIES}

The resistance of alkaline phosphatase isoenzyme fractions to heating at $65^{\circ} \mathrm{C}$ for 10 minutes was studied. ${ }^{3}$ Plastic sample cups for the Cobas Bio were prewarmed to $65^{\circ} \mathrm{C}$ in a water bath (Grant Instruments, Cambridge, England). Sample (100 $\mu \mathrm{l})$ was added to each cup at 15 second intervals and incubated at $65^{\circ} \mathrm{C}$ for exactly 10 minutes. Serum was used in preference to plasma to avoid fibrinogen precipitation at this temperature. Immediately after incubation cups were placed directly on ice for exactly one minute and then stored at $4^{\circ} \mathrm{C}$ until analysis. Alkaline phosphatase activity remaining after heat treatment was determined in duplicate for each isoenzyme fraction using the instrument settings listed in table 1 (column A).

\section{Results}

INHIBITION WITH GUANIDINE HYDROCHLORIDE For all four isoenzymes used in this study similar inhibition to that previously described, ${ }^{4}$ with $0.3 \mathrm{~mol} / 1$ guanidine hydrochloride, was found-that is, $14 \%$, $47 \%, 90 \%$, and $124 \%$ of the total activity remained in the presence of this inhibitor for the bone, liver, intes? tinal and placental isoenzymes, respectively.

\section{INHIBITION WITH L-PHENYLALANINE}

In contrast to guanidine hydrochloride, the noncompetitive inhibition observed for each isoenzyme with L-phenylalanine was linear with time (figure) for all concentrations of this reagent investigated; such analyses were performed using the instrument settings listed in table 1 (column C).

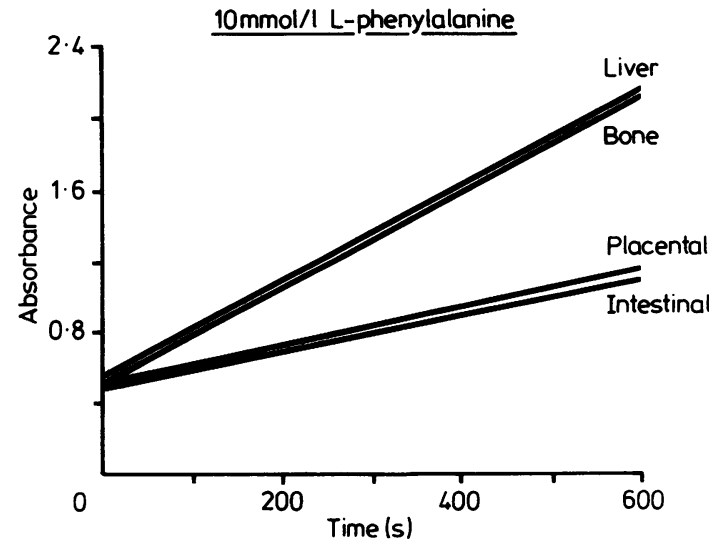

Figure Inhibition of bone, liver, intestinal, and placental isoenzymes using $10 \mathrm{mmol} / \mathrm{l}$ L-phenylalanine*.

*Initial total activities of each fraction of $500 \mathrm{U} / \mathrm{l}$. 
Table 2 Inhibition of alkaline phosphatase isoenzymes at varying concentrations of L-phenylalanine

\begin{tabular}{|c|c|c|c|c|c|c|}
\hline \multirow[b]{2}{*}{ Isoenzyme preparation } & \multirow{2}{*}{$\begin{array}{l}\text { Total activity } \\
(U / I)\end{array}$} & \multicolumn{5}{|c|}{ Percentage activity remaining at various $L$-phenylalanine concentrations $(\mathrm{mmol} / \mathrm{l})$} \\
\hline & & $2 \cdot 5$ & 5 & 10 & 20 & 50 \\
\hline $\begin{array}{l}\text { Bone } \\
\text { Liver } \\
\text { Intestinal } \\
\text { Placental }\end{array}$ & $\begin{array}{l}498 \\
502 \\
515 \\
499\end{array}$ & $\begin{array}{l}97 \\
97 \\
62 \\
68\end{array}$ & $\begin{array}{l}92 \\
93 \\
48 \\
55\end{array}$ & $\begin{array}{l}86 \\
86 \\
33 \\
36\end{array}$ & $\begin{array}{l}76 \\
75 \\
22 \\
20\end{array}$ & $\begin{array}{r}52 \\
52 \\
10 \\
8\end{array}$ \\
\hline
\end{tabular}

*The values reported for each concentration of L-phenylalanine are the mean of 10, five, 15, two, and two independent sets of data, respectively.

Table 2 shows the percentage activity remaining for each isoenzyme in the presence of varying concentrations of L-phenylalanine. For the intestinal fraction, the percentage activity remaining in the presence of $2 \cdot 5,5$, and $10 \mathrm{mmol} / 1 \mathrm{~L}$-phenylalanine was shown to be independent of the temperature at which the reaction was carried out $\left(25^{\circ} \mathrm{C}, 30^{\circ} \mathrm{C}\right.$, or $\left.37^{\circ} \mathrm{C}\right)$.

L-Phenylalanine $(10 \mathrm{mmol} / \mathrm{l})$ was selected as the concentration of choice for this inhibitor. At this concentration, optimal discrimination between the bone and liver isoenzymes, on the one hand, and the intestinal and placental fractions on the other was observed; furthermore, the total activity of both bone and liver isoenzymes was reduced by only $14 \%$ at this concentration.

\section{HEAT STABILITY STUDIES}

Bone, liver, intestinal and placental isoenzymes, each separately diluted with saline to about $1000 \mathrm{U} / 1$, were heated at $65^{\circ} \mathrm{C}$. After heat treatment bone and liver isoenzyme activity was completely destroyed after two and a half minutes, while the placental fraction retained total activity for more than 10 minutes.
The intestinal isoenzyme, diluted in saline, showed partial resistance to the effect of heat, with $55 \%, 30 \%$, and $10 \%$ of the total activity remaining after heating for two and a half minutes, five, and 10 minutes, respectively. This intestinal sample was then further diluted in saline to obtain samples with activities of 500,250 , and $50 \mathrm{U} / \mathrm{l}$; on heating these samples for 10 minutes, some activity remained; the percentage activity remaining being inversely related to the activity of intestinal alkaline phosphatase.

To resolve this unexpected finding the use of an alternative diluent was investigated. A serum based diluent with zero alkaline phosphatase activity was prepared using heat inactivation. Intestinal samples with a similar concentration range to those in saline were prepared using this diluent and then subjected to heat treatment. In contrast to the results found using saline as diluent, zero activity remained in all intestinal samples prepared using a serum based diluent. This has also been our experience with all undiluted patient sera containing intestinal alkaline phosphatase. Previous workers have shown that maintenance of $\mathrm{pH}$ is critical in heat stability studies. ${ }^{5}$ Vari-

Table 3 Percentage inactivation of bone, liver, intestinal and placental isoenzymes diluted to various activities using both serum and saline

\begin{tabular}{|c|c|c|c|c|c|c|c|}
\hline \multirow[b]{3}{*}{ Isoenzyme source } & \multirow[b]{3}{*}{ Activity $(U / l)$} & \multicolumn{6}{|c|}{ Percentage activity remaining } \\
\hline & & \multicolumn{2}{|c|}{ Phenylalanine $(10 \mathrm{mmol} / \mathrm{l})$} & \multicolumn{2}{|c|}{ Guanidine hydrochloride $(0 \cdot 3 \mathrm{~mol} / \mathrm{l})$} & \multicolumn{2}{|c|}{ Heat $65^{\circ} \mathrm{C} / 10$ minutes } \\
\hline & & Saline & Serum & Saline & Serum & Saline & Serum \\
\hline \multirow{4}{*}{ Bone } & 1000 & 86 & 86 & 14 & 13 & 0 & 0 \\
\hline & 500 & 86 & 87 & 13 & 14 & 0 & 0 \\
\hline & 250 & 85 & 86 & 15 & 14 & 0 & 0 \\
\hline & 50 & 86 & 85 & 14 & 15 & 0 & 0 \\
\hline \multirow[t]{4}{*}{ Liver } & 1000 & 86 & 86 & 47 & 47 & 0 & 0 \\
\hline & 500 & 86 & 85 & 48 & 47 & 0 & 0 \\
\hline & 250 & 86 & 86 & 47 & 48 & 0 & 0 \\
\hline & 50 & 85 & 86 & 46 & 47 & 0 & 0 \\
\hline \multirow[t]{4}{*}{ Intestinal } & 1000 & 33 & 33 & 90 & 89 & 10 & 0 \\
\hline & 500 & 34 & 35 & 91 & 88 & 16 & 0 \\
\hline & 250 & 33 & 33 & 89 & 89 & 20 & 0 \\
\hline & 50 & 34 & 33 & 91 & 91 & 38 & 0 \\
\hline \multirow[t]{4}{*}{ Placental } & 1000 & 68 & 68 & 124 & 124 & 100 & 100 \\
\hline & 500 & 70 & 68 & 122 & 126 & 100 & 100 \\
\hline & 250 & 69 & 67 & 123 & 124 & 100 & 100 \\
\hline & 80 & 68 & 69 & 125 & 122 & 100 & 100 \\
\hline
\end{tabular}


Table 4 Mean responses of isoenzymes to guanidine hydrochloride, L-phenylalanine, and heat

\begin{tabular}{lcll}
\hline & \multicolumn{2}{l}{ Percentage activity remaining after treatment $(\%)$} \\
\cline { 2 - 4 } & $\begin{array}{l}\text { Guanidine } \\
\text { hydrochloride }\end{array}$ & $\begin{array}{l}\text { L-Phenylalanine } \\
(10 \mathrm{mmol} / \mathrm{l})\end{array}$ & $\begin{array}{l}\text { Heat } \\
\left(65^{\circ} \mathrm{C} / 10 \text { minutes }\right)\end{array}$ \\
Isoenzyme & $(0.3 \mathrm{~mol} / \mathrm{l})$ & $(10 \%$ & 0 \\
Bone & $14 \%$ & $86 \%$ & 0 \\
Liver & $47 \%$ & $86 \%$ & 0 \\
Intestinal & $90 \%$ & $33 \%$ & 100 \\
Placental & $124 \%$ & $36 \%$ & \\
\hline
\end{tabular}

able heat inactivation observed with increased dilution of intestinal extracts in saline requires further investigation.

\section{ENZYME ACTIVITY AND PERCENTAGE}

INACTIVATION

After this preliminary data had been considered studies were then undertaken to investigate the effect of varying enzyme activity on percentage inactivation.

Dilutions were prepared in both serum and saline for each of the bone, liver, placental and intestinal fractions to give concentrations of $1000,500,250$ and $50 \mathrm{U} / 1$. Guanidine hydrochloride and L-phenylalanine inhibition and heat stability studies were performed on all samples. Table 3 summarises the results. Percentage inactivation was shown to be independent of enzyme concentration; further, there was no difference in the results obtained between the saline and serum dilutions, except for the heat stability of the intestinal isoenzyme as described above.

Table 4 summarises the mean response of each isoenzyme to guanidine hydrochloride, L-phenylalanine, and heat (under the reaction conditions specified).

ALGORITHM FOR THE RESOLUTION OF

ALKALINE PHOSPHATASE ISOENZYMES

Based on the assumption that the total alkaline phos- phatase activity (T) is the sum of the bone (B), liver (L), intestinal (I) and placental (P) fractions, and that the heat stable fraction $(\mathrm{H})$, guanidine hydrochloride stable fraction $(\mathrm{G})$, and L-phenylalanine stable fraction (A) similarly represent the sum of the relative contribution of individual isoenzyme components, the following set of equations summarise these responses:

$$
\begin{aligned}
& \mathrm{T}=\mathrm{B}+\mathrm{L}+\mathrm{I}+\mathrm{P} \\
& \mathrm{H}=100 \mathrm{P} \\
& \mathrm{G}=1.24 \mathrm{P}+0.90 \mathrm{I}+0.47 \mathrm{~L}+0.14 \mathrm{~B} \\
& \mathrm{~A}=0.36 \mathrm{P}+0.33 \mathrm{I}+0.86 \mathrm{~L}+0.86 \mathrm{~B}
\end{aligned}
$$

By solving these equations in the sequence placental, intestinal, liver, and bone, the following algorithm for the quantitative determination of each alkaline phosphatase isoenzyme fraction can be derived:

$$
\begin{aligned}
& \mathrm{P}=1.0 \mathrm{H} \\
& \mathrm{I}=1.6226 \mathrm{~T}-1.8868 \mathrm{~A}-0.9434 \mathrm{P} \\
& \mathrm{L}=-0.4242 \mathrm{~T}-2.3030 \mathrm{I}-3.3333 \mathrm{P}+3.0303 \mathrm{G} \\
& \mathrm{B}=\mathrm{T}-(\mathrm{P}+\mathrm{I}+\mathrm{L})
\end{aligned}
$$

ABILITY OF METHOD TO RESOLVE ISOENZYME MIXTURES

Guanidine hydrochloride and L-phenylalanine inhibition and heat stability studies were then carried out in duplicate on each individual isoenzyme fraction and on mixtures of these isoenzymes. Table 5 documents the stability of each isoenzyme and mixtures of isoenzymes to each method of inactivation.

The ability of the algorithm to resolve these isoenzyme mixtures was then tested; the results found using the algorithm were compared with the expected results (table 6) and show that for these mixtures the isoenzyme composition could be resolved to within $\pm 3 \%$. Day to day precision studies were carried out

\begin{tabular}{|c|c|c|c|c|}
\hline \multirow[b]{2}{*}{ Mixture } & \multirow[b]{2}{*}{ Total } & & & \\
\hline & & Heat stable & $\begin{array}{l}\text { Guanidine hydrochloride } \\
\text { stable }\end{array}$ & $\begin{array}{l}\text { L-phenylalanine } \\
\text { stable }\end{array}$ \\
\hline $100 \mathrm{~B}$ & 491 & 0 & 65 & 422 \\
\hline $100 \mathrm{~L}$ & 504 & 0 & 233 & 436 \\
\hline $100 I$ & 512 & 0 & 441 & 163 \\
\hline $100 \mathrm{P}$ & 519 & 528 & 629 & 181 \\
\hline 50B:50L & 497 & 0 & 150 & 430 \\
\hline 50B:50P & 498 & 259 & 342 & 302 \\
\hline 50B:50I & 505 & 0 & 265 & 299 \\
\hline 50P:50L & 507 & 259 & 434 & 310 \\
\hline 50P:50I & 511 & 264 & 546 & 179 \\
\hline 50L:50I & 508 & 0 & 342 & 310 \\
\hline 25B:25L:25I:25P & 505 & 130 & 350 & 305 \\
\hline
\end{tabular}
using a $50 \%$ bone: $50 \%$ liver mixture and a $50 \%$ intestinal: $50 \%$ placental mixture; the results summarised in table 7 show that the method has acceptable reproducibility.

Table 5 Guanidine hydrochloride, L-phenylalanine and heat inhibition studies on bone (B), liver (L), intestinal (I), and placental $(P)$ isoenzymes and mixtures of these individual isoenzymes

Alkaline phosphatase (U/l)

All analyses were carried out in duplicate in a single experiment. Values represent the mean of the duplicate results. 
Table 6 Ability of proposed method to correctly quantitate known amounts of individual isoenzymes and mixtures of isoenzymes

\begin{tabular}{|c|c|c|c|c|}
\hline \multirow[b]{2}{*}{ Mixture } & \multicolumn{2}{|l|}{ Expected result } & \multicolumn{2}{|c|}{ Measured result (using algorithm) } \\
\hline & $(U / l)$ & Percentage of total & $(U / l)$ & Percentage of total \\
\hline $\begin{array}{l}\text { 100B } \\
100 \mathrm{~L} \\
100 \mathrm{I} \\
100 \mathrm{P} \\
50 \mathrm{~B}: 50 \mathrm{~L} \\
50 \mathrm{~B}: 50 \mathrm{P} \\
50 \mathrm{~B}: 50 \mathrm{I} \\
50 \mathrm{P}: 50 \mathrm{~L} \\
50 \mathrm{P}: 50 \mathrm{I} \\
50 \mathrm{~L}: 50 \mathrm{I} \\
\text { 25B:25L:25I:25P }\end{array}$ & $\begin{array}{l}491 \\
504 \\
512 \\
519 \\
245: 252 \\
242: 256 \\
247: 258 \\
257: 250 \\
257: 254 \\
252: 256 \\
123: 125: 128: 129\end{array}$ & $\begin{array}{l}100 \\
100 \\
100 \\
100 \\
49 \cdot 3: 50 \cdot 7 \\
48 \cdot 6: 51 \cdot 4 \\
48 \cdot 9: 51 \cdot 5 \\
50 \cdot 7: 49 \cdot 3 \\
50 \cdot 3: 49 \cdot 7 \\
49 \cdot 6: 50 \cdot 4 \\
24 \cdot 3: 24 \cdot 8: 25 \cdot 3: 25 \cdot 6\end{array}$ & $\begin{array}{l}490 \\
492 \\
524 \\
528 \\
253: 244 \\
239: 259 \\
249: 256 \\
259: 235 \\
264: 242 \\
268: 240 \\
119: 135: 121: 130\end{array}$ & $\begin{array}{l}99 \cdot 9 \\
97 \cdot 7 \\
102 \cdot 4 \\
101 \cdot 7 \\
51 \cdot 0: 49 \cdot 0 \\
48 \cdot 0: 52 \cdot 0 \\
49 \cdot 3: 50 \cdot 7 \\
51 \cdot 1: 46 \cdot 5 \\
51 \cdot 7: 47 \cdot 4 \\
52 \cdot 8: 47 \cdot 2 \\
23 \cdot 7: 26 \cdot 5: 24 \cdot 1: 25 \cdot 8\end{array}$ \\
\hline
\end{tabular}

DEVELOPMENT OF AGE AND SEX RELATED REFERENCES RANGES

Age and sex related reference ranges were derived for each isoenzyme. Serum from 300 apparently healthy subjects was used for this purpose, with 50 men and 50 women in each of three age groups (A) 20-39 years, (B) 40-59 years, and (C) about 60 years of age. The data were processed using non-parametric statistics; table 8 summarises the results.

In agreement with other investigators, ${ }^{810-12}$ we found that bone and liver alkaline phosphatase contributed about half of the total alkaline phosphatase activity in normal adult subjects. Liver alkaline phosphatase activity showed a small increase with age in both men and women. Bone alkaline phosphatase activity was higher in men than in women in the 20-39 age group $(p<0.01)$. In contrast, women had a higher bone alkaline phosphatase activity for subjects aged about 60 years $(p<0.01)$. A significant peak in bone alkaline phosphatase in women between the ages of 50 and 60 has recently been reported and related to postmenopausal changes in sex hormones. ${ }^{12}$ When the 50 women in group B were further divided into subjects aged 40-49 $(n=32)$ and subjects aged 50-59 $(\mathrm{n}=18)$, the mean bone alkaline phosphatase activity was $22 \mathrm{U} / 1$ in the younger group and $30 \mathrm{U} / 1$ in the older group. For women in group $\mathrm{C}$, bone alkaline phosphatase further increased to $36 \mathrm{U} / 1$. These results, although with a smaller number of subjects, are consistent with the previously mentioned report. ${ }^{12} \mathrm{~A}$ small amount of intestinal alkaline phosphate activity was detected in all groups.

\section{CLINICAL EVALUATION}

A detailed clinical study was then undertaken to validate the method using patient material and to evaluate its usefulness in various clinical situations. One hundred and one patients with raised total alkaline phosphatase activity were randomly selected for investigation. Total, guanidine stable, phenylalanine stable, and heat stable alkaline phosphatase activities were determined on these samples and, using the algorithm, placental, intestinal, liver, and bone isoenzymes were quantitated. The following biochemical variables were also measured on each specimen: urea concentration, creatinine concentration; total protein value; albumin concentration; calcium concentration; inorganic phosphate activity; alanine aminotransferase activity; bilirubin concentration; and $\gamma$ glutamyltransferase activity. Clinical diagnosis was established by the senior medical specialist in the department after consultation with the clinicians responsible for the management of each patient.

Results of the clinical study (table 9) were catego-

Table 7 Day to day precision studies using 50\% placental:50\% intestinal mixture and 50\% liver:50\% bone mixture

\begin{tabular}{|c|c|c|c|c|c|c|}
\hline & \multirow{3}{*}{$\begin{array}{l}\text { Total } \\
\text { activity } \\
(U / l)\end{array}$} & \multicolumn{5}{|c|}{ Isoenzyme mixture } \\
\hline & & \multicolumn{2}{|c|}{ Placental:intestinal } & \multirow{2}{*}{$\begin{array}{l}\text { Total } \\
\text { activity } \\
\text { (U/l) }\end{array}$} & \multicolumn{2}{|l|}{ Liver:bone } \\
\hline & & $(U / l)$ & Percentage & & $(U / l)$ & Percentage \\
\hline $\begin{array}{l}\text { Expected } \\
\text { Mean } \\
\text { SD } \\
\text { CV (\%) } \\
\text { n }\end{array}$ & $\begin{array}{r}511 \cdot 0 \\
513 \cdot 3 \\
5.9 \\
1 \cdot 2 \\
8\end{array}$ & $\begin{array}{c}257 \cdot 0: 254 \cdot 0 \\
263 \cdot 7: 247 \cdot 0 \\
5 \cdot 4: 9 \cdot 6 \\
2 \cdot 0: 3 \cdot 9 \\
8\end{array}$ & $\begin{array}{c}50 \cdot 3: 49 \cdot 7 \\
51 \cdot 4: 48 \cdot 1 \\
1 \cdot 5: 1 \cdot 3 \\
2 \cdot 9: 2 \cdot 7 \\
8\end{array}$ & $\begin{array}{r}497.0 \\
496.0 \\
6.5 \\
1.3 \\
15\end{array}$ & $\begin{array}{c}252 \cdot 0: 245 \cdot 0 \\
240 \cdot 3: 253 \cdot 6 \\
6 \cdot 7: 10 \cdot 2 \\
2 \cdot 8: 4 \cdot 0 \\
15\end{array}$ & $\begin{array}{c}50 \cdot 9: 49 \cdot 2 \\
48 \cdot 5: 51 \cdot 1 \\
1 \cdot 6: 1 \cdot 6 \\
3 \cdot 3: 3 \cdot 1 \\
15\end{array}$ \\
\hline
\end{tabular}


Table 8 Age and sex related reference ranges for alkaline phosphatase isoenzyme activity

\begin{tabular}{|c|c|c|c|c|c|c|c|c|c|c|c|c|c|}
\hline \multirow[b]{2}{*}{$\begin{array}{l}\text { Subjects } \\
\text { (age in years) }\end{array}$} & \multicolumn{4}{|l|}{ Total } & \multicolumn{3}{|c|}{ Intestinal } & \multicolumn{3}{|l|}{ Liver } & \multicolumn{3}{|l|}{ Bone } \\
\hline & $\begin{array}{l}\text { Mean } \\
\text { Age }\end{array}$ & No & $\begin{array}{l}\text { Mean } \\
(U / l)\end{array}$ & $\begin{array}{l}\text { Range } \\
(U / I)\end{array}$ & $\begin{array}{l}\text { Mean } \\
(U / I)\end{array}$ & $\begin{array}{l}\text { Range } \\
(U / I)\end{array}$ & $\begin{array}{l}\text { Percentage } \\
\text { of total }\end{array}$ & $\begin{array}{l}\text { Mean } \\
(U / l)\end{array}$ & $\begin{array}{l}\text { Range } \\
(U / I)\end{array}$ & $\begin{array}{l}\text { Percentage } \\
\text { of total }\end{array}$ & $\begin{array}{l}\text { Mean } \\
(U / l)\end{array}$ & $\begin{array}{l}\text { Range } \\
(U / l)\end{array}$ & $\begin{array}{l}\text { Percent } \\
\text { of total }\end{array}$ \\
\hline \multicolumn{14}{|l|}{ Men } \\
\hline $20-39$ & 31 & 50 & 81 & $51-112$ & 5 & $0-15$ & 6 & 40 & $18-72$ & 49 & 36 & $19-59$ & 44 \\
\hline $40-59$ & 49 & 50 & 77 & $50-109$ & 4 & $0-13$ & 5 & 45 & $23-68$ & 58 & 28 & $16-43$ & 36 \\
\hline$>60$ & 61 & 50 & 82 & $64-111$ & 4 & $0-14$ & 5 & 48 & $26-73$ & 58 & 30 & $8-60$ & 36 \\
\hline All & 47 & 150 & 80 & $50-112$ & 5 & $0-15$ & 5 & 44 & $18-73$ & 55 & 31 & $8-60$ & 39 \\
\hline \multicolumn{14}{|l|}{ Women } \\
\hline $20-39$ & 30 & 50 & 61 & $40-94$ & 3 & $0-13$ & 5 & 33 & $16-64$ & 54 & 25 & $12-38$ & 41 \\
\hline $40-59$ & 48 & 50 & 70 & $48-110$ & 3 & $0-13$ & 5 & 41 & $21-74$ & 59 & 25 & $13-45$ & 36 \\
\hline$>60$ & 62 & 50 & 84 & $64-106$ & 5 & $0-15$ & 6 & 43 & $21-71$ & 51 & 36 & $19-56$ & 42 \\
\hline All & 47 & 150 & 72 & $40-110$ & 4 & $0-15$ & 6 & 39 & $16-74$ & 54 & 29 & $12-56$ & 40 \\
\hline Total & 47 & 300 & 76 & $40-112$ & 5 & $0-15$ & 6 & 42 & $16-74$ & 55 & 30 & $8-60$ & 39 \\
\hline
\end{tabular}

No placental isoenzyme was detected in these normal subjects.

rised into one of three groups:

(i) In 80 patients the source and cause of the raised serum alkaline phosphatase activity was established through clinical diagnosis and other pathology tests. In all these cases the isoenzyme results were compatible with the clinical diag- nosis.

(ii) In 10 patients the source of the raised alkaline phosphatase activity was clinically unknown. The source was identified by isoenzyme analysis, which in turn led to further clinical investigations and a firm diagnosis being made.

Table 9 Clinical evaluation of alkaline phosphatase (ALP) isoenzyme method

Group 1 Source and cause of raised plasma ALP identified from clinical diagnosis and confirmed by assay Pathological Liver:

Secondary carcinoma

Cholelithiasis

Cirrhosis/alcohol

Hepatitis

Congestive cardiac failure

Drug reaction

Ischaemia

Trauma

Bone:

Pagets disease

Secondary carcinoma

Uraemic osteodystrophy

Osteomalacia

Physiological:

Thyrotoxicosis

Age related

Pregnancy

Group 2 Source unknown (identified by assay and leads to diagnosis)

One isoenzyme raised:

Liver:

Cholelithiasis

Cirrhosis of liver

Bone:

Paget's disease

Osteomalacia

Secondary carcinoma of bone

Two isoenzymes raised (source and cause of one known):

Liver and bone: Alcoholic liver disease and osteomalacia

Alcoholic liver disease and Paget's disease

Alcoholic liver disease and Paget's
Hepatitis and renal osteodystrophy

Group 3 Source identified but definite clinical diagnosis yet to be made

One isoenzyme raised:

Liver:

Cyclophosphamide treatment

Amphotericin treatment

Carotid artery disease

Total parenteral nutrition

Bone:

Carcinoma of colon

Renal calculi

Urinary infection/Parkinson's disease

Superficial thrombophlebitis

Two isoenzymes raised (cause and source of one known):

Liver and bone:

Acute hepatitis

Alcoholic liver disease

Dialysis 
In seven cases one isoenzyme fraction was raised, in three cases two isoenzymes components were raised, one of which was not suspected.

(iii) In 11 patients the source of the raised alkaline phosphatase activity was identified and verified using electrophoresis, but a definite clinical diagnosis is yet to be made. In eight cases a single isoenzyme fraction was raised. In three cases two isoenzymes were raised, the source and cause of only one of which was known.

\section{CASE ILLUSTRATING USE OF THE METHOD (from group ii)}

An 81 year old man was admitted with a three day history of chills and fever. Clinical examination showed that he was poorly nourished. His liver was enlarged to $2 \mathrm{~cm}$ below the costal margin, but otherwise the physical examination was unremarkable. On admission the following serum biochemical results were noted (reference ranges in parentheses): total protein concentration $70 \mathrm{~g} / \mathrm{l}(65-80)$; albumin concentration $39 \mathrm{~g} / 1$ (30-50); alkaline phosphatase activity $251 \mathrm{U} / 1$ (30-120); alanine aminotransferase activity $18 \mathrm{U} / 1 \quad(<40) ;$ bilirubin concentration $12 \mu \mathrm{mol} / 1$ $(<20)$.

The raised serum alkaline phosphatase activity and the hepatomegaly suggested liver disease. The normal ALT values, however, made this diagnosis doubtful. To investigate this problem further the serum sample with a total alkaline phosphatase of $251 \mathrm{U} / 1$ was then subjected to inhibition using heat, L-phenylalanine, and guanidine hydrochloride under the final reaction conditions specified. The activity remaining after treatment was as follows: heat $\left(65^{\circ} \mathrm{C}\right.$ for 10 minutes) $0 \mathrm{U} / \mathrm{l}$; L-Phenylalanine $(10 \mathrm{mmol} / \mathrm{l}) 216 \mathrm{U} / \mathrm{l}$; guanidine hydrochloride $(0.3 \mathrm{~mol} / \mathrm{l}) 59 \mathrm{U} / \mathrm{l}$.

Application of the algorithm resulted in the following activities for each isoenzyme: placental, $0 \mathrm{U} / 1$ (reference range 0); intestinal, $2 \mathrm{U} / 1 \mathrm{l}(1 \%)$ (reference range $0-15)$; liver, $72 \mathrm{U} / 1(29 \%)$ (reference range 16-74); bone, $177 \mathrm{U} / 1(71 \%)$ (reference range 8-60). The results indicated that bone was in fact the source of the raised serum alkaline phosphatase activity. Further investigations including a plasma vitamin D concentration of $22 \mathrm{nmol} / 1$ (reference range 40-160) ultimately led to an (initially unsuspected) diagnosis of osteomalacia.

\section{CASE ILLUSTRATING CORRECTIQN FOR \\ PLACENTAL ISOENZYME}

When present, the importance of placental isoenzyme on the measurement of the activities of other isoenzymes should not be overlooked: a 30 year old woman in late pregnancy with a raised serum alkaline phosphatase activity of $202 \mathrm{U} / 1$ was investigated.
Selective inhibition with heat, L-phenylalanine, and guanidine hydrochloride gave the following results of remaining activity: heat $\left(65^{\circ} \mathrm{C}\right.$ for 10 minutes) $98 \mathrm{U} / \mathrm{l}$; 1-phenylalanine ( $10 \mathrm{mmol} / \mathrm{l}) 125 \mathrm{U} / \mathrm{l}$; guanidine hydrochloride $(0.3 \mathrm{~mol} / \mathrm{l}) 161 \mathrm{U} / \mathrm{l}$.

Application of the algorithm resulted in the following activities for each isoenzyme: placental, $98 \mathrm{U} / 1$ (49\%) (reference range 0$)$; intestinal, $0 \mathrm{U} / 1$ ( $0 \%$ ) (reference range $0-15)$; liver, $76 \mathrm{U} / 1$ (37\%) (reference range 16-74); bone, $28 \mathrm{U} / 1$ (14\%) (reference range 8-60). Thus placental alkaline phosphatase activity was the principal component, and no significant abnormalities in liver or bone isoenzyme activities were detected.

In contrast with earlier three isoenzyme methods, ${ }^{78}$ the placental alkaline phosphatase activity of $98 \mathrm{U} / 1$ does not interfere with the measurement of other isoenzymes using our method, because its activity has been carefully measured using heat inhibition and the activity of placental alkaline phosphatase using Lphenylalanine and guanidine hydrochloride has been included in our algorithm. Failure to do this will firstly result in placental alkaline phosphatase activity being measured as intestinal (although it might reasonably be assumed that this is mostly placental in serum from a pregnant subject, as both these forms of alkaline phosphatase exhibit similar stability to Lphenylalanine). The liver component, however, will be grossly overestimated and the bone component underestimated due to the greater stability of placental alkaline phosphatase to guanidine hydrochloride (or urea) than the liver isoenzyme. Table 10 shows the errors introduced in a three isoenzyme algorithm.

A three isoenzyme method thus suggests a raised liver isoenzyme activity and a negative bone isoenzyme activity. The advantage of the proposed method in the presence of either suspected or unsuspected placental or carcinoplacental alkaline phosphatase becomes clear.

\section{Conclusion}

In summary, rapid and reproducible methods for the determination of guanidine hydrochloride, L-phenylalanine, and heat stable alkaline phosphatase activities were developed using the Cobas Bio centrifugal analyzer at $37^{\circ} \mathrm{C}$. Using a simple mathematical algo-

Table 10 Errors introduced in three enzyme algorithm

\begin{tabular}{lcl}
\hline Enzyme or isoenzyme & $\begin{array}{l}\text { Four isoenzyme } \\
\text { algorithm (U/l) }\end{array}$ & $\begin{array}{l}\text { Three isoenzyme } \\
\text { algorithm (U/l) }\end{array}$ \\
\hline Placental & 98 & $\mathrm{P}+\mathrm{I}=92$ \\
Intestinal & 0 & \\
Liver & 76 & 191 \\
Bone & 28 & -81 \\
Total & 202 & 202 \\
\hline
\end{tabular}


rithm, these activities were used to quantitatively determine the contribution of each isoenzyme fraction to the total alkaline phosphatase activity.

As the total activity, L-phenylalanine stable, and heat stable activities can all be performed in a single analytical run on the Cobas Bio, the total analysis time for the quantitative determination of alkaline phosphatase isoenzymes was about 30 minutes.

The ability of the method to accurately resolve mixtures of isoenzymes, including placental alkaline phosphatase, was confirmed. Age and sex related reference ranges for each isoenzyme fraction were determined. The method was validated in a study of over 100 patients and was shown to be clinically useful in a variety of situations.

We thank Mr John Glover for his computing assistance with this project and we acknowledge the support and encouragement of Dr G White throughout this study.

\section{References}

1 Moss DW. Alkaline phosphatase isoenzymes. Clin Chem 1982;28:2007-16

2 Rosalki SB, Foo AY. Incubation with neuraminidase and affinity electrophoresis with wheat-germ lectin compared for separating and quantifying alkaline phosphatase isoenzymes in plasma. Clin Chem 1985;31:1198-200.

3 Rosalki SB, Foo AY. Two new methods for separating and quantifying bone and liver alkaline phosphatase isoenzymes in plasma. Clin Chem 1984;30:1182-6.

4 Shephard MDS, Peake MJ. Quantitative method for the determination of serum alkaline phosphatase isoenzyme activity I. Guanidine hydrochloride: a new reagent for selectively inhibiting the major serum isoenzymes of alkaline phosphatase. J Clin Pathol 1986;39:1025-30.

5 Neale FC, Clubb JS, Hotchkis D, Posen S. Heat stability of human placental alkaline phosphatase. J Clin Pathol 1965;18:359-65.

6 Fishman WH, Sie HG. Organ-specific inhibition of human alkaline phosphatase isoenzymes of liver, bone, intestine and placenta: L-phenylalanine, L-tryptophan and L-homoarginine. Enzymologia 1971;41:141-67.

7 Statland BE, Nishi H, Young DS. Serum alkaline phosphatase: total activity and isoenzyme determinations made by use of the $\vec{\theta}$ centrifugal fast analyser. Clin Chem 1972;18:1468-74.

8 O'Carroll D, Statland BE, Steele BW, Burke MD. Chemical inhibition method for alkaline phosphatase isoenzymes in human serum. Am J Clin Pathol 1975;63:574-62.

9 Solbert HE. The theory of reference values. Part 5. Statistical 8 treatment of collected reference values, determination of refer- $\omega$ ence limits. J Clin Chem Clin Biochem 1983;21:749-60.

10 Whitaker KB, Whitby LG, Moss DW. Activities of bone and liver alkaline phosphatases in serum in health and disease. Clin Chim $\overrightarrow{0}$ Acta 1977;80:209-20.

11 Stepan J, Volek V, Kolar J. A modified inactivation-inhibition method for determining the serum activity of alkaline phosphatase isoenzymes. Clin Chim Acta 1976;69:1-9.

12 Stepan JJ, Tesarova A, Havranek T, Jodl J, Formankova J, $\mathcal{Q}$ Pacovsky V. Age and sex dependency of the biochemical indices of bone remodelling. Clin Chim Acta 1985;151:273-83.

Requests for reprints to: Mr MDS Shephard, Department of Biochemistry and Chemical Pathology, Flinders Medicg Centre, Bedford Park, South Australia 5042, Australia. 